\title{
Representation Of Muslim Women In E-Media Caricatures
}

\author{
Azka Khan \\ \& \\ Sarwet Rasul \\ Department of English \\ Fatima Jinnah Women University
}

\begin{abstract}
This paper attempts to gain an understanding of the ways in which Muslim women are presented on the E-media in the broader world community by identifying and examining the linguistic and visual signifiers used in the caricatures. The sample selected for the current research work consists of 22 caricatures disseminated on the World Wide Web between years 2012 - 2013. From a theoretical perspective, the socio-cognitive approach to CDA introduced by Van Dijk (1992, 1993, 2000, 2012) on communication of ethnic biases and racial prejudices is combined with the visual semiotic model by Roland Barth (1978). The two approaches are merged to examine linguistic and visual aspects of caricatures for identifying signs which construct certain identities of Muslim women. This paper argues that in the collected caricatures the identity of Muslim women is constructed as distant and different from the (Western) social norm. The iconic images or visual identifiers used, function to transfer all the biased imagery and prejudice about Muslim women to the actual situation. Thus they serve the purpose to authenticate the stereotypical identity. This paper claims that the social caricatures collected, depict racial and ethnic prejudices against Muslim women.
\end{abstract}

Keywords: Muslim Women, E-Media, Caricatures.

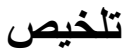

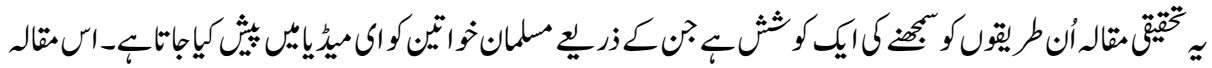

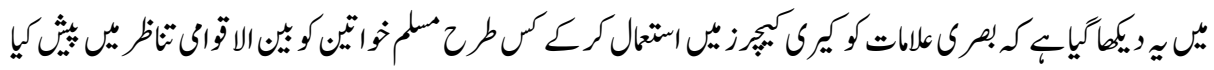

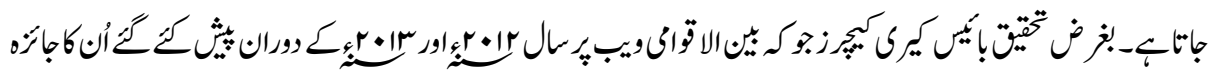

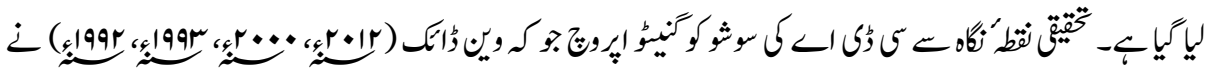

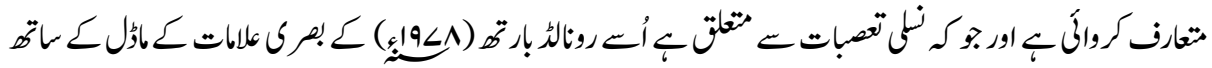

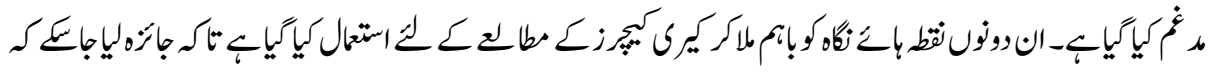

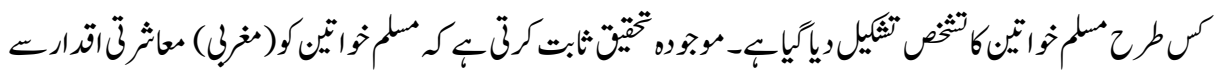




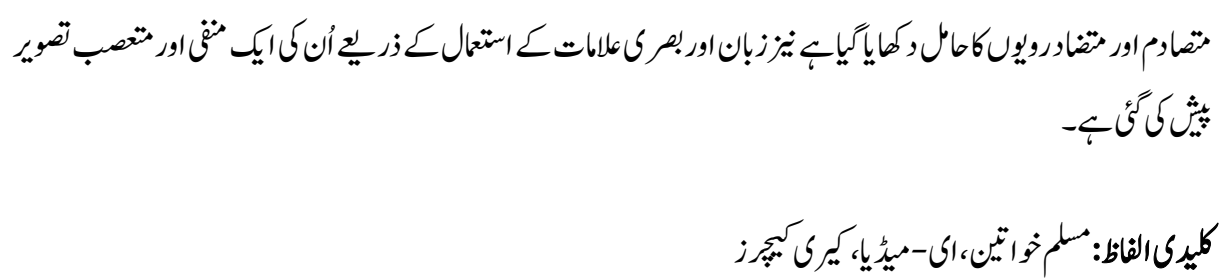

\section{Introduction and Literature Review of the Current Research}

The ground breaking work by Edward Said - Orientalism (1979) - increased an interest in the construction of Muslim identity. This included newspapers, film industry, personal blogs and academic books. The recent research works in the domain of identity construction have mainly focused on film industry, Shaheen (2003) print media (Akbarzadeh \& Smith 2005) fictional and non-fictional writings (Ridouani, 2011) etc.

\section{Neo-Orientalism and Identity of Muslim Women}

Alloula (1986) demonstrate the effects of the French colonization of Algeria, (1830-1962) through postcards of Algerian women produced and circulated in France. The Algerian Muslim women were portrayed as an evidence of backward, exotic and strange customs of Algeria. Most of the women shown were victims of war, prostitutes or orphans who were asked to pose for the camera but the postcards portrayed as if the camera is capturing a real moment of everyday life. Aloula (1986) claims that these photos carry no names and the impersonal captions such as "Women from the south" and "Women from Algiers" project an image of the Oriental women with common names like "The beautiful Fatima". This study exposes the practice of conceptualizing and reinforcing an image of erotic Muslim women.

Bullock (2002) suggests that after World War II, orientalism took a new shape and has transformed into neo-orientalism. The western world analyzed the non-Western world with the assumption of the inherent superiority of Western culture considering it a pre requisite for progress. This resulted in suggestions that in order to progress, the under developed or third world countries need to evolve into Western style institutions. Bullock (2002) suggests that the mainstream Western electronic and print media rely and propagate this belief which is at times used to establish a case against Islam (Bullock 2002).

\section{Politics of Veil}

Many researchers Alsultany (2012, 2013) Majumdar (2009) Jarmakani (2008) Hoodfar (1993) have debated that 'the Muslim woman' is produced as a social policy in discourses in the West. Kahf (1999) suggests that Muslim women are neither empowered 
nor oppressed by the presence or absence of the veil but by the presence or absence of economic, political, and family rights both on national and international levels. Rashid (2013) uses the title "Veiled Threats" for exploring the stereotypical notions attached to veil. She argues that the trope of 'the Muslim woman' must be deconstructed and individual differences must be understood.

Bullock (2002) suggests that West has at least three different notions attached to the Muslim veil. The crudest and most unsophisticated view of the veil emerging out of an unconscious adherence to liberalism and modernization theory is held by people of the mainstream and pop culture who consider veil a symbol of Muslim women's complete subjugation by Muslim men. Another comparatively convoluted view is held by the people who are usually more knowledgeable about Islamic history. This group is also concerned about the Muslim women's rights but their majority does not listen attentively to the voices of the veiled women or do not find Muslim women's arguments persuasive. The result is their continued belief that even a satisfying life in the veil is an oppressed life. The third school of western thought consists of the anthropologists and historians who listen to the marginalized voices of covered women. Their subject demands to understand veil as a social practice but their methodological approach helps them reach a different conclusion from that of the mainstream Western liberal thinking. This group generally blames Muslim society believing that the social upbringing of the Muslim women is responsible for the continued veiling practices.

\section{E-Media Caricatures as a Powerful Weapon}

Since the sample of this article consists of selected caricatures, it would be appropriate to discuss the medium of caricatures that is used for the construction of the identity of Muslim women. The term has its roots in the Italian word "caricare" (Encyclopaedia Britannica). A caricature is an impressionistic drawing made to create humorous effects and consists of exaggerated prominent physical characteristics (Walker, 2003). The graphic satire in caricatures can also deal with a group by incorporating characteristics of the group as the subject of a caricature.

Midalia (1999) debates that caricatures are usually not innocent and neutral reflections of the reality and involve an intentional interpretation of it. The message they convey is absorbed easily owing to the seemingly innocent humor. Walker (2003) argues that this humorous intervention in the construction of a caricature leads to shaping the public opinion. Oz (2014) argues that caricatures are contextualized activities which consists of exaggerated forms of conceptual metaphors, symbols and illusions. The concretization of these concepts is vital enough and even does not need objectivity or truthfulness. 
Bisson (2014) explores the heavier side of the caricatures and claims that at times the political cartoons not only evoke anger but also offend, either intellectually or accidentally. Bisson's conclusion demands serious attention that some of the political cartoons not only become hate speech, they also incite violence. She quotes, a radical cartoonist, Art Young who said, "To have a life as a cartoonist of the kind whose pictures "never hurt' is my idea of futility" (Dewey n.d. as cited in Bisson, 2014, p.68).

\section{Problem Statement and Significance of the Research}

In today's world ideologies are created, maintained and exploited to practice the relations of power and dominance. The media is covering Muslim women not only in news articles and works of fiction but they are also portrayed in cartoons and caricatures in a negative way. Owing to the commonsensical nature of caricatures, these discriminatory discourses have a stronger impact. They function to legitimize the ideological discrimination tacitly. In this context the current research is an effort to deconstruct the stigmatized representation of Muslim women by identifying the representational strategies used in the art of caricaturing.

\section{Aim of the Current Research}

The general aim of this research is to gain an understanding of the ways in which the Emedia presents and shapes the identity of Muslim women in the broader world community. This includes identifying different semiotic signifiers and examining linguistic devices used in the selected caricatures.

\section{Research Questions}

The current research is guided by the following questions:

- What images of Muslim women are most frequently represented in the E-media; and how certain identities related to them are being created in E-media caricatures?

- What socio-semiotic symbols are used in the collected caricatures to construct the Muslim women identity; and how do these semiotic symbols relate to the accompanying linguistic expressions?

\section{Sampling Strategy for the Current Research}

For the current research non-probability purposive sampling strategy is used which involves selecting cases with a specific purpose in mind (Neumann, 1992). The sample caricatures for the current research work are collected with the main aim to explore the representation of Muslim Women. The selection of caricatures is not systematically 
controlled per artist or per news websites. A general search on the Google Images search engine is carried out by using the following key words:

- Muslim woman caricatures lcartoons

- Pardah caricature

- Burqa caricatures

○ Muslim woman images

- Islam phobic caricatures

A conscious effort is made to keep the statements neutral in their connotation but to find out whether there are "unsupportive" or "negative" imagery dispersed on the World Wide Web, another "counter search" is also carried out with these keywords.

- Funny Muslim woman caricatures

○ Ridiculing Muslim Women through caricatures

The change in keywords had no effect on the results. At a third research level, the terms "Muslim women images" is used and the word "caricatures" is omitted. The word caricature in itself carries a negative connotation as it is a visual satire. The consistency in the search results implied that similar caricatures related to Muslim women identity are widely used on different blogs and websites. The collected sample is further filtered for the presence of at least one linguistic statement. Finally only those caricatures are included which are disseminated on the E-media in the two year time from January 2012 - December 2013.

\section{Theoretical Framework}

Since the sample consists of caricatures and accompanying linguistic items, an in-depth analysis demanded that Socio-cognitive approach to CDA by Van Dijk (1991, 1992, 2012) is merged with the semiotic analysis of Roland Barthe (1978).

\section{1) Semiotic Model and Tools}

Barthe's model utilizes two orders of signification for deriving meaning from the images. The first order of signification or the denotative meaning is the literal or descriptive meaning apparent to every skimmer of the caricatures. The second order of signification

or the connotative meaning is derived when the first order of signification is inserted into the value system of that culture.

\section{2) Cognitive Dimensions of Social Attitudes By Van Djik}

Van Djik's socio-cognitive approach (SCA) $(1987,1992,2012)$ to CDA is based on the assumption that biases are communicated because of the prejudiced social attitudes of the 
in-group members about the members of out-group. He explains that prejudice is something more than negative ethnic attitudes of in-group members. (1987, P.181) Communication of prejudiced ideas cannot be simply described as a "mental state;" rather it involves flexible strategies. These flexible strategies function at different cognitive levels of the speaker or writer which are called social information processing by Van Dijk. These strategies not only involve just "what" people think about the Other, but it also involves "how" they do so" (Van Djik, 1987, p.182).

\section{Strategies for Communicating Biased Attitudes as Given by Van Dijk}

\section{i. Social Categorization}

Expression of biased discourse involves perception of real or imagined differences between the in-group and the out-group. It is termed as the Social Categorization by Van Dijk. These differences between groups may range from differences of origin, nationality, ethnicity, race, language, gender, class, occupation, status, education, or appearance. etc. (Van Dijk 1987, p.196).

\section{ii. Negative Evaluation}

The next strategic step, negative evaluations are a logical result of social categorization. SCA suggests that the in-group assumes that a specific out-group possess properties which are incompatible with those of their own, they will definitely be evaluated negatively.

\section{iii. Empirical "Bias"}

The third step explained by Van Dijk, is development and expression of empirical bias about the other. This bias may have its roots in individual perceptions and experiences but ends in generalized models and attitude about the oppressed group. Based on these theoretical underpinnings, analytical categories for the current research are devised.

\section{Analytical Categories Devised for the Current Research}

Two analytical categories have emerged out of the collected sample of the Muslim women caricatures which have been divided into following sub-categories:

\section{Muslim Woman's Appearance}

1.a Muslim woman as a Stooge

1.b Muslim woman as Cuckold

2. Muslim Woman's Social Role

2.a Muslim Woman as Oppressed and Ignorant

2.b Muslim Woman as a Social Recluse 


\section{Muslim Woman's Appearance}

It is observed that the distinctive dressing practices of Muslim women is a favorite topic of discussion for the caricaturists. Twelve caricatures are found directly involved in the identity construction of Muslim women on the basis of her appearance. Veil and hijab as the most frequent iconic representation of a Muslim woman appeared in all the caricatures collected for this study and thus it seems reasonable here to explain what is meant by the word hijab. The word hijab comes from the Arabic word "hajaba" which means to hide or conceal from view. Muslims live in diverse cultures and civilizations, so the dress of a Muslim woman usually carries the expression of their local customs expressed through the terms including Hijab, Chador, Nikaab/ Niqab, Burqa, Jilbab etc.

It is found that all the caricatures included in this section make fun of the dressing of the Muslim women but they differ in two ways. In six caricatures the target of ridicule is the practice of veiling. No other issue of significant importance is discussed in these whereas in the rest of the caricatures the Muslim woman is represented as lustful and unfaithful. Based on these two basic differences the caricatures have been arranged under the following headings:

1.a Muslim woman as a Stooge

1.b Muslim woman as Cuckold

\section{1.a Muslim Woman as a Stooge}

The caricatures included in this section (fig1-7) make fun of the Muslim woman's appearance and the target of ridicule remains burqa, hijab or veil. Two caricatures are discussed as exemplars of the 7 caricatures included in this section. Fig 2 is one such caricature in which four human figures are visible. A burqa clad woman is shown standing in front of three other male human figures. The linguistic item in the speech bubble tells the viewer about her inability to understand the reaction of common people to her burqa. The speech bubble carries the statement, "I don't understand why people react to me with fear and suspicion."(Fig 2) The humorous nature of the intended message of the artist may be understood by cautiously examining the appearance of human figures present in the cartoon. After observing carefully the viewer realizes that the burqa clad women is standing in front of a small group of hooligans, scoundrels and rogues. Two of them are holding dangerous weapons in their hands, an axe and a revolver. These unreliable people have covered their faces and they are not identifiable. The under handedness in this caricature is nullifying the objection made by the women in burqa. The question posed by woman becomes meaningless when her appearance is compared with the human figures in front of her. She should realize it that by covering her face completely she is standing in the category of suspicious people of society. She should expect to be treated with the same feelings of suspicions and mistrust which are found in 
the society for the scoundrels. The third human figure has got a specific historical background. The costume confirms a person from an organization called Klu Klux Klan. This organization was originally founded as a social club in Tennessee in 1865; however, later on it was blamed for involvement in political and social terrorism.

The presupposition working in this type of caricatures is that the choice of dressing must be in accordance with the demands of the society. If someone chooses to follow one's personal choices which are unacceptable to the society, one should be ready to face undesirable consequences. Thus the burqa clad woman should not be amazed or irritated by the suspicion which she arouses because of her appearance. Such racist discourses serve the purpose of normalization and naturalization of the bias. They make the discriminating attitudes appear natural. Instead of raising voice against discrimination, they serve the purpose of silencing the marginalized voices.

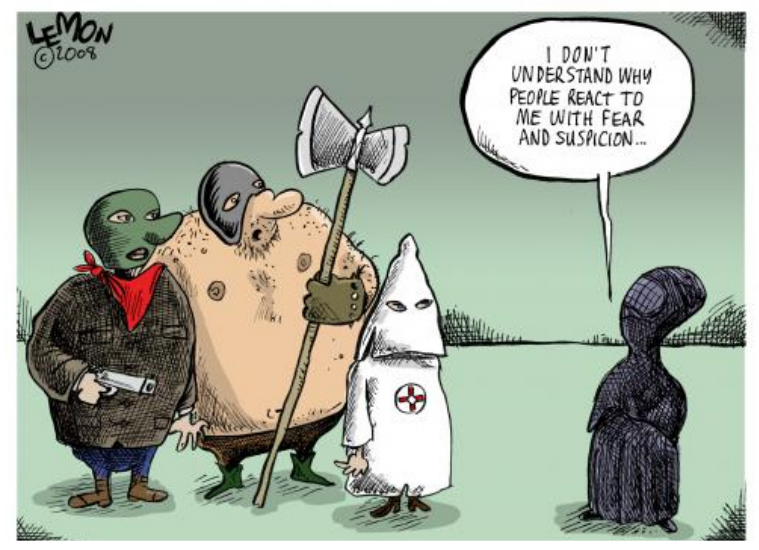

FIG 2

Fig 4 belongs to the category which is termed as multi-phasic picture by Sonesson (1988). The caricature consists of three panels arranged in a chronological order. This arrangement helps the reader to develop a minimal narrative statement which shows spatial and temporal relationship between these panels. The first panel has two burqa clad women and serves the purpose of engaging the skimmer. The subsequent panel is arranged immediately after the first one without leaving the "gutter" between the panels. This decidedly builds up the curiosity of the reader but the message is still not clear. The second panel shows the amplified and blown up image of the woman in burqa in the background. This exaggerated figure keeps the reader wondering but the mystery is not solved until the skimmer observes the third panel. The third panel carries a speech bubble in which the word "gesundheit" can be read. This term demands explanation. 


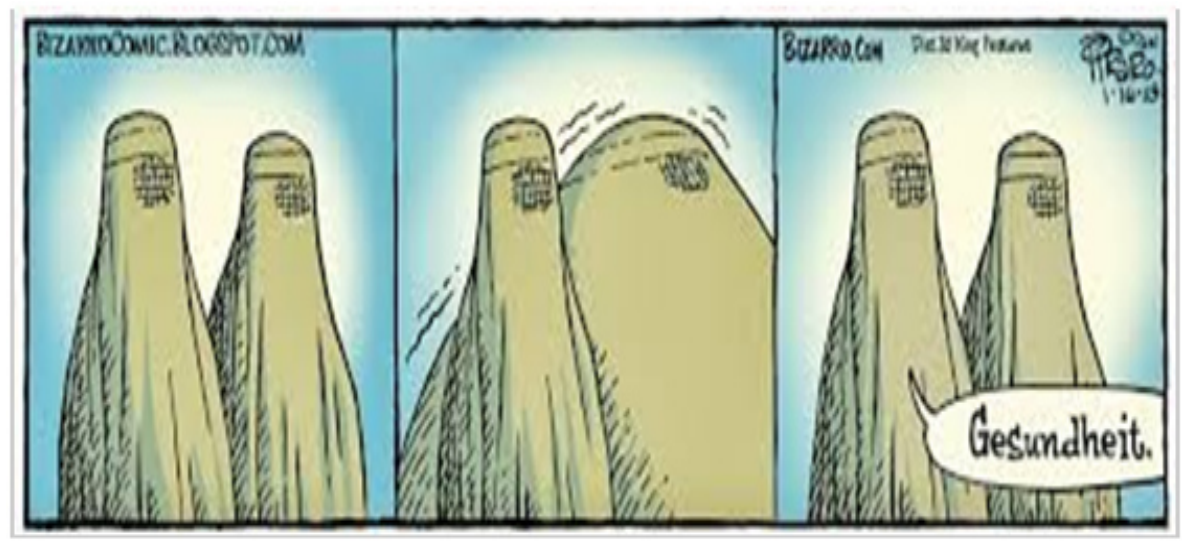

Fig. 4

The word gesundheit (German origin) is one of the sneezing etiquettes. We are accustomed to hearing "bless you" in English but in Germany it is more polite to say gesundheit (Upton, 2012). It is surprising that the caricaturist did not use the Arabic phrase "Alhamdolillah" which is more common in the Muslim countries. This word consists of two words, "gesund" which means "health" whereas the suffix "heit" which means "hood" (Merriam-Webster's dictionary, 2003). The word gesundheit literally means "healthy hood". The image can be now analyzed for its temporal and spatial relations of the panels as a humorous story. The temporal relation of these panels is of immediate succession. This implies that the initial position of the second panel comes immediately after the final position of the first panel. This temporal arrangement leaves no room for the mediate or delayed succession which is suggested by the absence of gutter too (Hébert, 2006).

A relation of unilateral dependence can be easily traced between burqa and the Muslim women. It is also suggested that this relation is unidirectional. This implies that the presence of a burqa presupposes the presence of a Muslim woman (since women of no other religion use this dress), but the presence of a Muslim woman does not presuppose the presence of a burqa (since there are many Muslim women who do not use this sort of robe for covering). The linguistic item written in a speech bubble has a pointed line in the direction of the Muslim woman placed in the foreground. It is easy for the skimmer to realize the cartoonist's take on this issue. It presents the Muslim women as a stooge. The purpose of this temporal set is nothing but making fun of the practice of wearing burqa. Even the linguistic item used to conceptualize the message is ironical in the situation. The appropriate sneezing etiquettes for this scheme should be Alhamdolillah. Instead of this common practice, a queer term gesundheit is used. The phenomenon may be explained by borrowing terms from Sonesson (1988) who called such a scheme monkey business because of the disconfirmed expectancies in pictorial schemes (p.40). This means that the 
skimmer does not expect the woman shown in the caricature to use this German etiquette of sneezing.

Figures 1, 5, and 7 (See appendix) also ridicule the Muslim woman by changing her into an unidentifiable object whereas fig 3 shows a car which is wrapped in a burqa. The language accompanying this figure not only points out the condition of Muslim women in Iran but also makes fun of the veiling practices of Muslim women (See appendix).

\section{1.b Muslim Woman as Cuckold}

Kahf (2010) suggests that the image of Muslim women has changed in the recent Western representations from "odalisque" to "termagant". She suggests that representing Muslim women as submissive and oppressed has under gone a change as some of the European writers have started portraying Muslim woman as a forceful queen of wanton who intimidates sexuality. The interesting thing about Politics of Muslim women oppression is that if a Muslim woman expresses her own desire to cover herself and chooses to use veil, the expected (and oft repeated) answer of the western scholars is quoted here in Kahf's words,

The classic Western and secular Muslim feminist answer to this sort of thing is condescending: women who aren't bothered by veiling just don't know any better, and one day, with guidance and continued freedom, they will be enlightened and stop veiling" ( $p .34,2010)$

Sample of the current research contains five caricatures that address the issue of burqa from a different angle: the concept of veil as an embodiment of modesty is a myth and veiled Muslim women are using it as a disguise to hide their lustful desires and waiting for the right moment to throw it away.

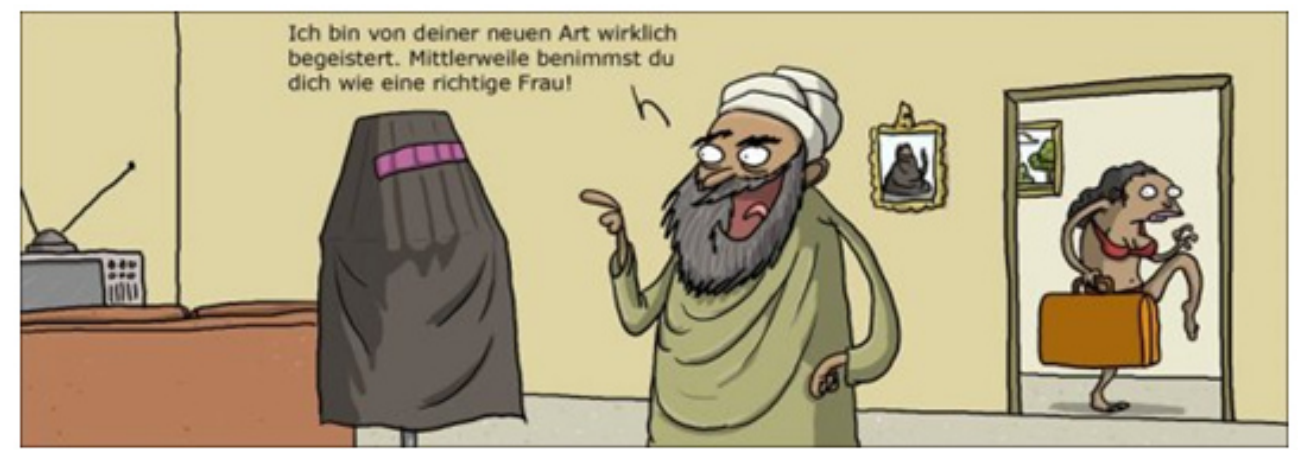

"I'm quite pleased with your new appearance. Now you are finally behaving like a proper woman!"

FIG 7 
Fig 7 is a visual manifestation of Muslim woman as a termagant. A long bearded man is standing in the middle of the image, pointing his figure to a burqa. His loose robe along with a traditional Muslim headdress helps his identification as a Muslim man. His widely open mouth and protruding big eyes make him appear as an unpleasant personality. The setting shows an inside home scene and the relationship appears to be of a husband and wife. He has uttered the statement written underneath. "I'm quite pleased with your new appearance. Now you are finally behaving like a proper woman!" The incongruity of the situation becomes clear to the skimmer by two things. One is the fact that the man is talking to a burqa standing erect on a wooden stand. This can be realized after observing the image carefully. The second thing which helps to realize the irony of situation is the image of a woman in a very brief bathing suit tiptoeing at the backdrop. She is holding a suitcase and appears to escape without telling her husband. The presence of the suitcase indicates that the stay would be overnight. Thus she is an embodiment of a cuckold woman who is unfaithful to her husband. Figs 8 to 12 (See appendix) suggest that Muslim women are trying to escape the strictness of Islamic rules.

\section{Muslim Woman's Social Role}

Majumdar (2009) had explored the processes that rendered Muslim women invisible in the social and political context of Bengal by tracing the past histories. Before her Jarmakani (2008), and Alloula (1986) have made similar proposition regarding role of Muslim women in different eras and area. The appropriateness of traditional clothing, particularly the head covering worn by some Muslim women, has been the focus of recent fierce media debates. In the debate over hijab, Muslim women are portrayed as veiled victims by the Western media in two ways: either as victims in need of liberation or as dupes who lack free choices. These two different representations helped in dividing the data into two sub-categories:

2.a Muslim Woman as Oppressed and Ignorant

2.b Muslim Woman as a Social Recluse

Both these categories are discussed below along with the sample caricatures.

\section{2.a Muslim Woman as Oppressed and Ignorant}

This section contains five caricatures portraying the idea that the practice of Muslim woman covering herself up is not her choice. 


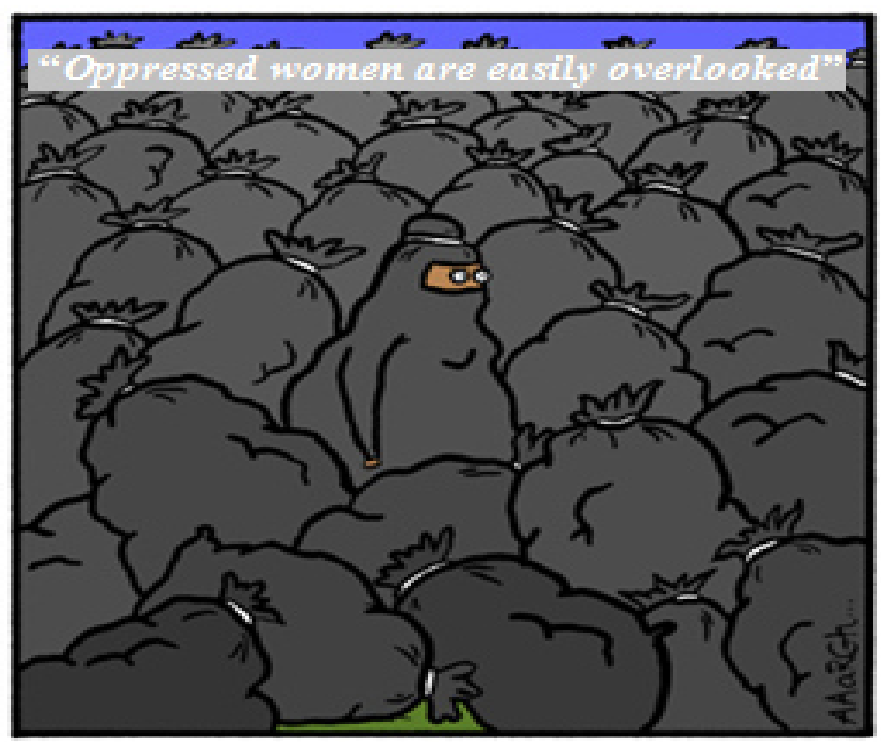

FIG 13

The idea presented in the five caricatures included in this section is that the Muslim woman is in need of help which generates the idea that foreign invasion is something inevitable and desirable. Muslim woman in burqa is used as a representative of humans clearly in need of "assistance". These images reinforce the belief that the religion Islam justifies oppressive cultural practices against women and reduces not only their status, freedom, ability to work, opportunity for proper education, facilities of healthcare but also the ability to exercise political rights.

A cursory glance at Figure 13, may not help the viewer realize that there is a woman in burqa placed in the middle of a heap of garbage bags. Through this unheeded appearance of the woman in burqa a very powerful and obvious statement is made about the Muslim society. The image under discussion illustrates two contradictory objects: a human being, presumably a Muslim woman clad in a burqa, and loads of bags of garbage. The placement of these two objects as well as the similarity of color implies that both are analogous. This placement of a Muslim woman in the midst of 'trash' gathers significance as the word trash is defined in the Word Web dictionary as: 1. "Worthless material that is to be disposed of"; 2. "Worthless people"; and 3. "statements or beliefs that are untrue or make no sense".

Thus Muslim women are equated to worthless or discarded material or objects. The lens used to view them is highly biased and prejudiced which serves to perpetuate the stereotype of the helpless, worthless, subjugated, devoid of intellectual activity, and 
voiceless Muslim woman. More importantly, her image in burqa intends to make the viewer believe that her liberation is necessarily related to removal of her burka. It is also worth noticing that if she was not wearing a burka, then the linguistic statement "oppressed women are easily overlooked," would no longer be valid for all the Muslim women only. The burka is receiving an inordinate amount of attention at the expense of other more important issues of health, education etc. The same idea is reiterated in Fig 15.

\section{Islamic Cartoons and Comics}

Islamic cartoon 1 of 20

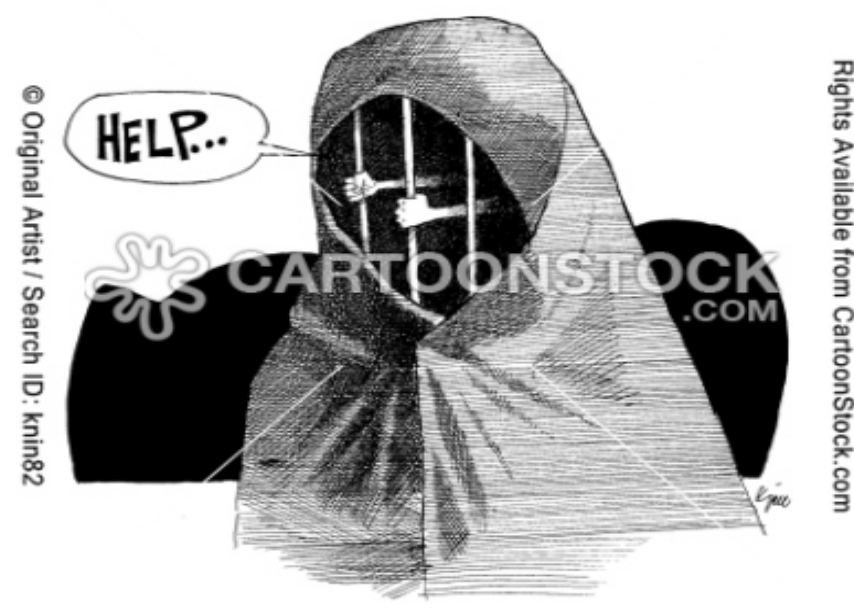

Women in Islam.

FIG 15

This caricature, which is yet another physical manifestation of an oppressed Muslim woman, shows a lone figure clad in "Chador" facing the viewer (Fig15). Two hands are shown behind the bars holding the bar tightly inside veil depicting powerlessness of a Muslim woman. The whole concept of chador is associated with that of a prison by making bars instead of a face. A callout "HELP" in capital letters is a cry for help. The ellipses show that the Muslim woman has much more to say but is silenced by the social pressures. The caption is reinforcing the overall message. The generalized statement "Woman in Islam" is meant for all Muslim women. The signified and signifier mutually reinforce the message received by the viewer. The strong contrast of black and white background is not without purpose. Black is always associated with oppression and horror. Instead of a face, inside of veil is shown black. No facial identity is given to this iconic representation of Muslim women, thus emphasizing their dehumanized image. 


\section{2.b Muslim Woman as a Social Recluse}

The identity creation of Muslim women as a social recluse is an outcome of a serious misconception about Islam and the Muslim society. In contrast to the Western idea of equality of sexes, Islam emphasizes the natural differences in their creation leading to the realization of different roles for both the sexes.

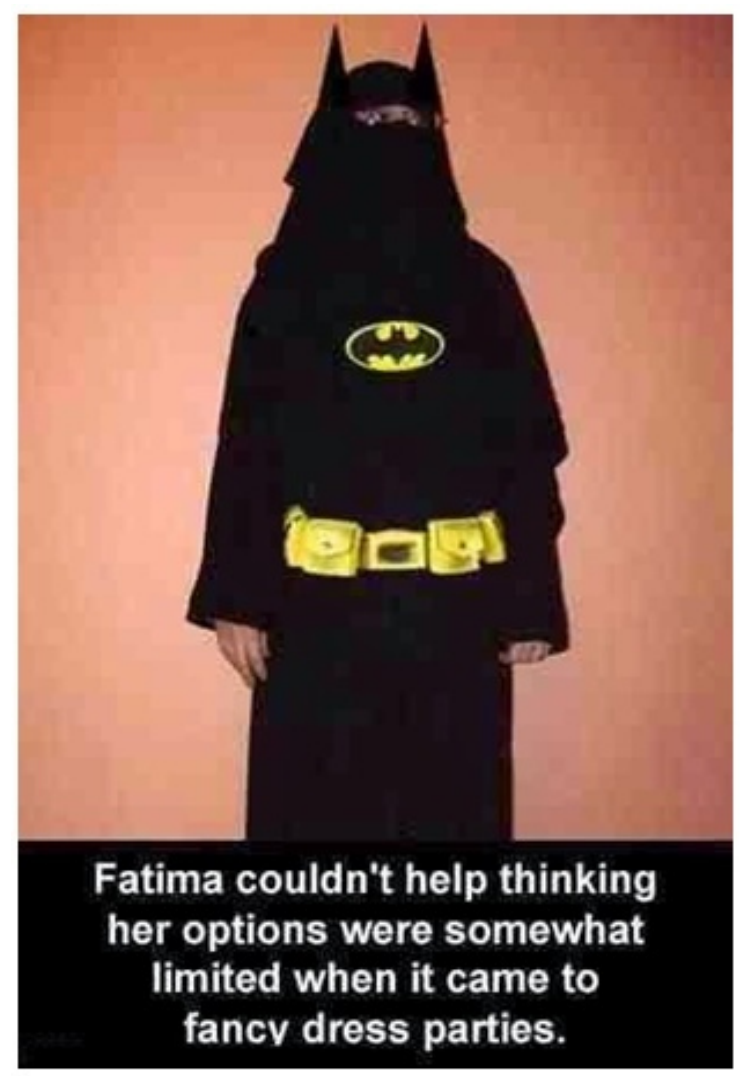

FIG 18

Fig 18 shows a woman covered in a black attire with only her eyes and hands visible. The caption reinforces the ideas suggested by Alloula (1986) that the name "Fatima" is a general name used for all the Muslim women. Here the cartoonist is mocking a Muslim woman dressed like a bat woman by saying that her veil has deprived her of all the social opportunities. The only option available to her in a fancy-dress- show is to dress like a bat man and cover her face under a mask. Fig 9 is a reiteration of the same views in a different way whereas Fig 19 shows a burqa clad woman searching for something in a shopping area. The caption underneath is "COSMETIC AISLE OXYMORON All She Needs is some Eye Shadow" (Fig 19). The intended message is that due to veil and hijab 
most of the makeup accessories are useless for her. All she needs is an eye shadow to make her eyes look beautiful. Thus, she is presented as a social recluse who has very limited opportunities of participation in social life.

\section{Conclusions}

The representation of Muslim women in the sample caricatures serves the purpose to authenticate the stereotypical identity of an oppressed and secluded set of women. The iconic images function to transfer the biased imagery and prejudice about Muslim women to the actual situation. They base their arguments on physical appearances so for instance Burqa is often ridiculed as a sign of aberrancy in these caricatures. Muslim women are presented not only as half-witted but also as cuckold and wayward. Representations in these caricatures gather significance because the mass audience of the West which has little interaction with real life situations of Muslims considers this subjective and biased conceptualization of Muslim women as objective and authentic. This paper claims that these caricatures operate as a rhetorical tool to construct a fabricated view of Muslim women as stooge, cuckold, oppressed, ignorant and a social recluse.

\section{References}

Akbarzadeh, S. \& Smith, B. (2005). The Representation of Islam and Muslims in the Media:(The Age and Herald Sun Newspapers). School of Political and Social Inquiry, Monash University.

Alloula, M. (2004). A Peep inside the Harem Retrieved on Jan 2015 from http://en.qantara.de /content/ malek-alloula -a-peep- inside- the- harem

Alloula, M. (1986). The Colonial Harem Minnesota: University of Minnesota Press.

Alsultany, E. (2012). Arabs and Muslims in the Media: Race and Representation after 9/11. NYU Press.

Alsultany, E. (2013). Arabs and Muslims in the Media after 9/11: Representational Strategies for a "Postrace" era. American Quarterly, vol.65:1, pp.161-169.

Barthes, R. (1977). Image-music-text, London: Fontana Press. 
Berger, A. A. (2004). Semiotic Analysis Retrieved Oct, 2014 from http://www.uk.sagepub.com/upm-data/5171_Berger_Final_Pages_Chapter_1.pdf

Bryant, J. M. (2002). Ku Klux Klan in the Reconstruction Era retrieved on 10 January 2014 from http://www.georgiaencyclopedia.org/articles/history-archaeology/kuklux-klan-reconstruction-era

Buel, J. W. (Ed.). (1904). Louisiana and the fair: An Exposition of the World, its People and their Achievements (Vol. 3). World's Progress Pub. Co.

Bullock, K. (2000). Challenging Media Representations of the Veil: Contemporary Muslim Women's Re-Veiling Movement, American Journal of Islamic Social Sciences, vol.17:3, pp.22-53.

Bullock, K. (2002). Rethinking Muslim Women and the Veil: Challenging Historical \& Modern Stereotypes. IIIT.

Gesundheit. (2003). In Merriam-Webster's dictionary (11th ed.). Springfield, MA.

Hoodfar, H. (1993). The Veil in their Minds and on Our Heads: The Persistence of Colonial Images of Muslim Women. Resources for Feminist Research, vol.22:3/4, pp.5-18.

Hebert, L. (2006). Tools for Text and Image Analysis: An Introduction to Applied Semiotics. E-Book, URL: http://www.revue-texto.net/Parutions/LivresE/Hebert_ AS/Hebert_Tools. html.

Jarmakani, A. (2008). Imagining Arab Womanhood: The Cultural Mythology of Veils, Harems, and Belly Dancers in the US. Granite Hill Publishers.

Jarmakani, A. (2008). Imagining Arab Womanhood: The Cultural Mythology of Veils, Harems, and Belly Dancers in the US. Palgrave Macmillan retrieved Dec 2014 from http://ebookandpdf.com/cultures-languages/58666-imagining-arabwomanhood-the-cultural-mythology-of.html

Majumdar, R. (2009). Processes That Rendered Muslim Women Invisible. Economic and Political Weekly, 44(28), 30-32. Retrieved from http://www.jstor.org/stable/40279257 
McCafferty, H. (2006). The Representation of Muslim Women in American Print Media: A Case Study of" The New York Times" September 11, 2000--September 11, 2002. ProQuest.

Mohanty, C. T. (2006). Under Western Eyes: Feminist Scholarship and Colonial Discourses. Media and Cultural Studies, 396.

Nordlund, M. (2003). Linguistic Manipulation: An Analysis of How Attitudes are Displayed in News Reporting.

Nunan David. (1992). Research Methods in Language Learning Cambridge University Press Retrieved on 09 September 2014 from: www.onlinelibrary.wiley.com

O’Keeffe, A. (2011) 'Media and Discourse Analysis', in Gee, J. \& Handford M. (eds), The Routledge Handbook of Discourse Analysis. London: Routledge, p 441-454.

Oz, S. (2014). The Construction of" the Turk" and the Entextualization of Historical Stereotypes in Political Cartoons in French (Doctoral dissertation, Arts \& Social Sciences: Department of French).

Pham, T. (2012). Satirical Depictions of the European Union: A Semiotic Analysis of Political Cartoons on the 2004 Enlargement and 2009-2012 Eurozone Debt Crisis.

Posetti, J. N. (2006). Media representations of the hijab Reporting Diversity - Journalism in Multicultural Australia (pp. 1-38) Australia : Australian Government.

Rashid, N. (2013). Veiled Threats: Producing the Muslim Woman in Public and Policy Discourse in the UK (Doctoral dissertation, The London School of Economics and Political Science (LSE)).

Reed, A. (2009). Muhammad as Representative Form: A Visual Rhetorical Analysis of the Danish Cartoon Controversy.

Rice-Sayre, L. (1986). Veiled Threats: Malek Alloula's Colonial Harem. Boundary 2, pp.351-363.

Said, E. W. (1979). Orientalism (1st Vintage Books ed.). NewYork, NY: Vintage Books.

Sarkar, M. (2001). Muslim Women and the Politics of (in) Visibility in Late Colonial Bengal. Journal of Historical Sociology, vol.14:2, pp.226-250. 
Sarkar, M. (2008). Visible Histories, Disappearing Women: Producing Muslim Womanhood in Late Colonial Bengal. Duke University Press.

Skaggs, S. (2011). Signs and Moments Two Branches: Continentalist and Peircean, retrieved on Jan 2015 from http: //stevenskaggs. net/ VDSP\% 20Chapt\%202.pdf

Smith, S. W. (2012). Cartoons and the New Anti-Semitism: A Thesis Presented in Fulfilment of the Requirements for the Degree of Master of Design at Massey University, College of Creative Arts, Wellington, New Zealand(Doctoral dissertation).

Sonesson, G. (1988). Methods and Models in Pictorial Semiotics. Lund: Lund University, vol.1:2, p.3.

Untitled Photograph of A Burqa Clad Woman with Garage Bags, Digital Image, Retrieved on Oct 2014 from http://www.barenakedislam.com/page/825/

UPTON, E. (2012). Why We Say Gesundheit When Someone Sneezes retrieved March, 2014 from http://www.Todayifoundout.com/index.php/2014/03/say-gesundheitsomeone-sneezes/s

Van Dijk, Teun A. (1993). Principles of Critical Discourse Analysis, Discourse \& Society, vol.4:2, pp.249-283.

Van Dijk, T. A. (1987). Communicating Racism: Ethnic Prejudice in Thought and Talk. Sage Publications, Inc.

Van Dijk, T. A. (1992). Discourse and the Denial of Racism. Discourse \& Society, vol.3:1, pp.87-118.

Van Dijk, T. A. (1995). Ideological Discourse Analysis, New Courant, vol.4:1, pp.135-161.

Van Dijk, T. A. (2000). The Reality of Racism, In Festschrift für die Wirklichkeit, VS Verlagfür Sozialwissenschaften, pp.211-225.

Van Dijk, T. A., (1991). Racism and the Press (p. 178). London: Routledge.

VanDijk, T. A. (2012). The Role of the Press in the Reproduction of Racism, Springer Vienna, pp.15-29. 
Walker, R. (2003). Political Cartoons: Now You See Them!. Canadian Parliamentary Review, vol.26:1.

Zine, J. (2002). Muslim Women and the Politics of Representation, American Journal of Islamic Social Sciences, vol.19:4, pp.1-22. 


\section{Muslim Women's Appearance \\ 1.1 Muslim woman as a Stooge}

\section{APPENDIX}

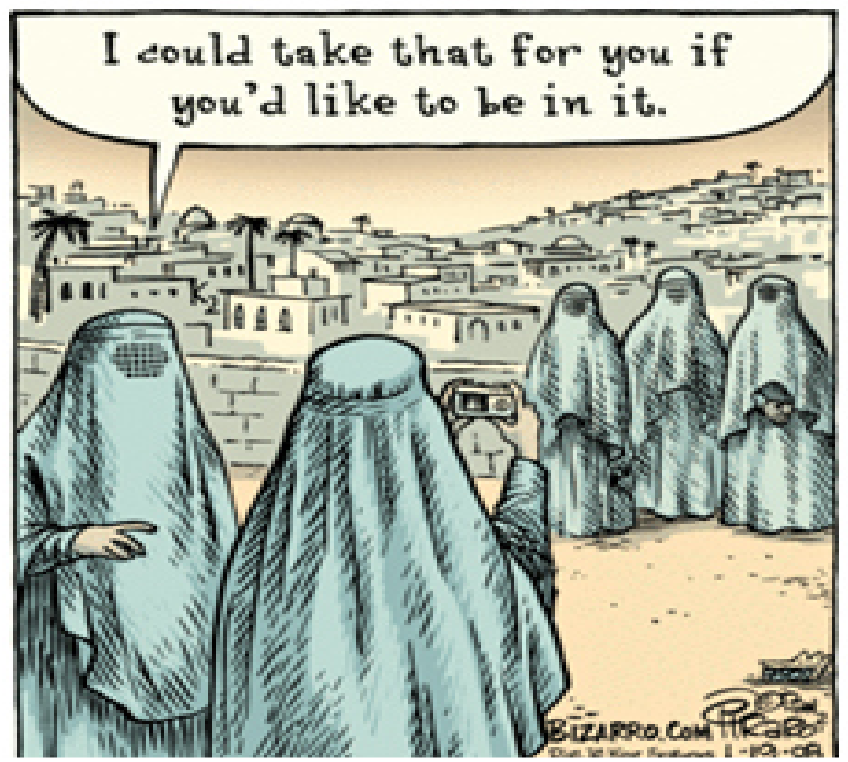

\section{FIG 1}

http://freethoughtblogs.com/taslima/2012/06/03/we-have-enough-muhammadcartoons-why-not-some-burqa-cartoons/

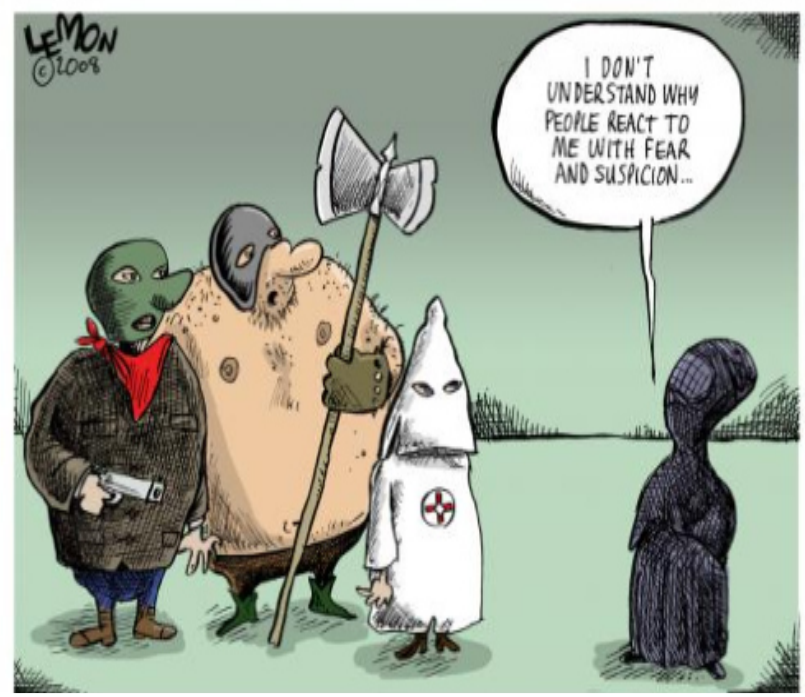

FIG 2

http://freethoughtblogs.com/taslima/2012/06/03/we-have-enough-muhammadcartoons-why-not-some-burqa-cartoons/ 


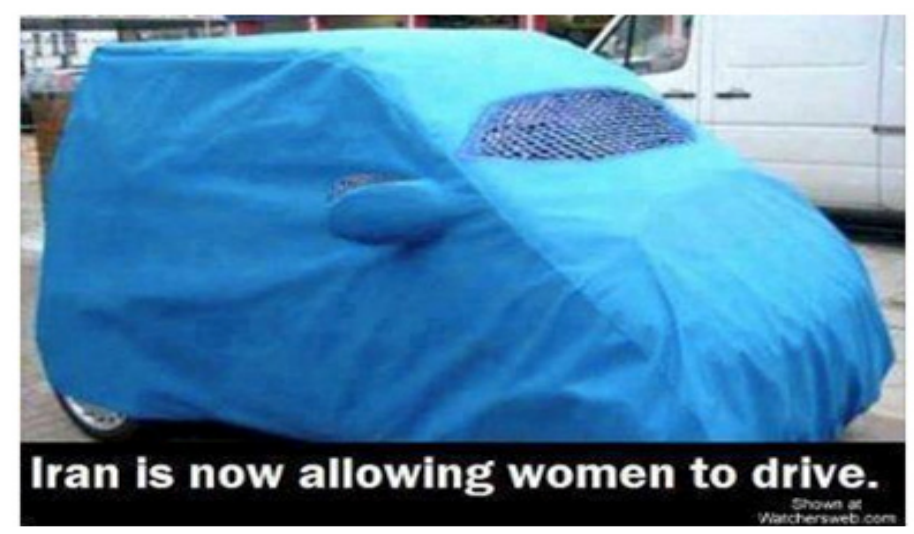

FIG 3

http://dr1.com/forums/clown-bin/133560-car-muslim-women.html

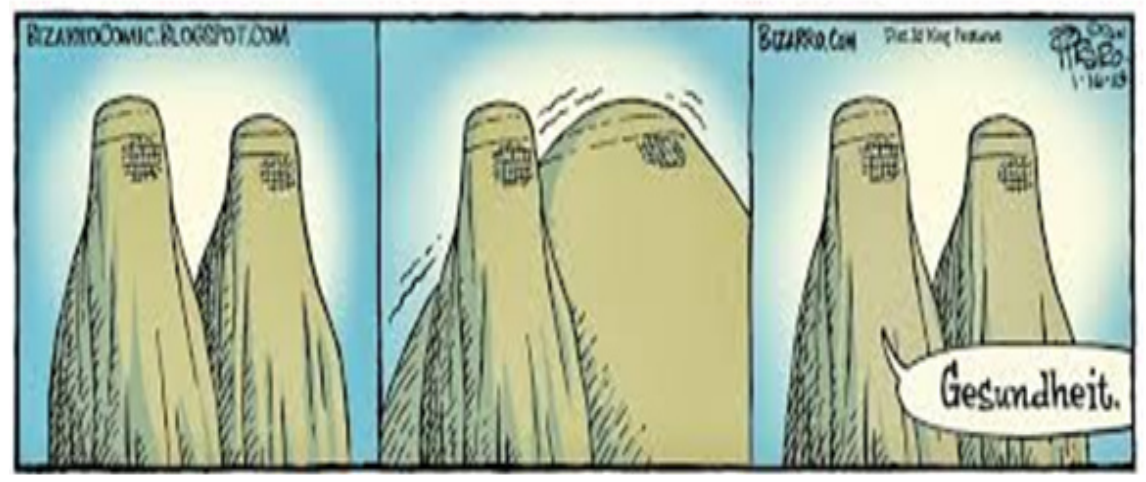

FIG 4

http://www.funny-joke-pictures.com/2013/09/funny-muslim-adam-even-gardeneden.html

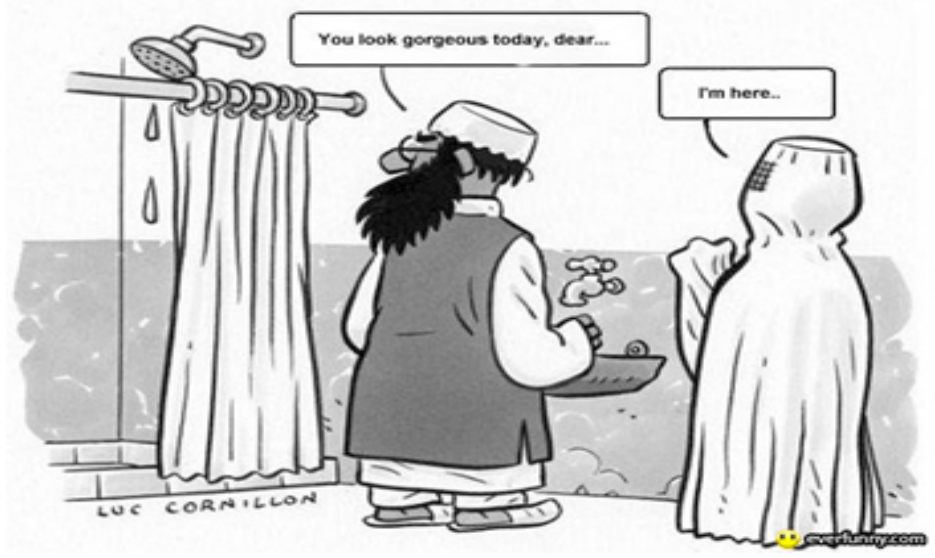

FIG 5

http://freethoughtblogs.com/taslima/2012/06/03/we-have-enough-muhammadcartoons-why-not-some-burqa-cartoons/ 


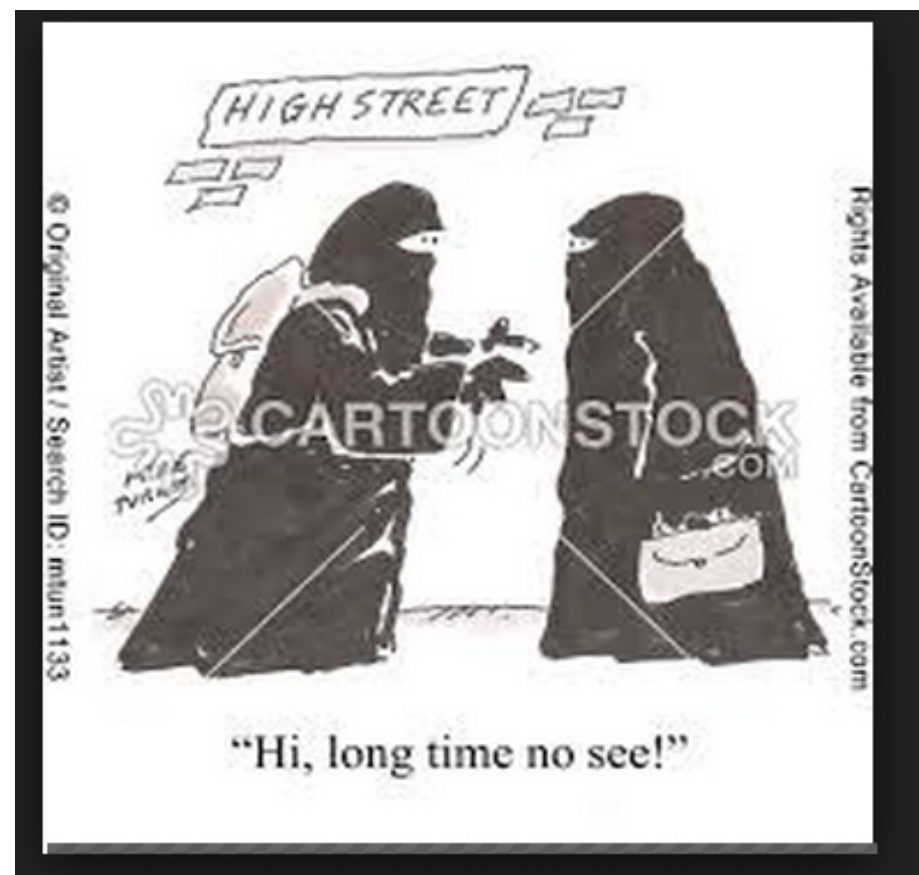

FIG 6

http://www.cartoonstock.com/directory/i/islamic.asp

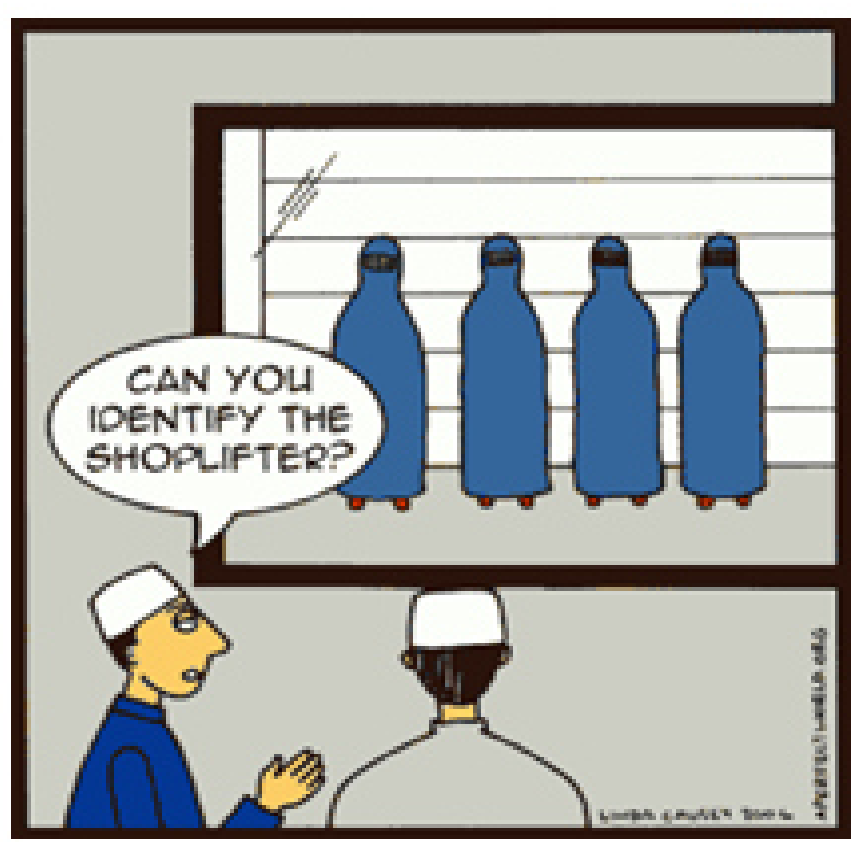

FIG 7

http://freethoughtblogs.com/taslima/2012/06/03/we-have-enough-muhammadcartoons-why-not-some-burqa-cartoons/ 


\subsection{Muslim Woman as Cuckold}

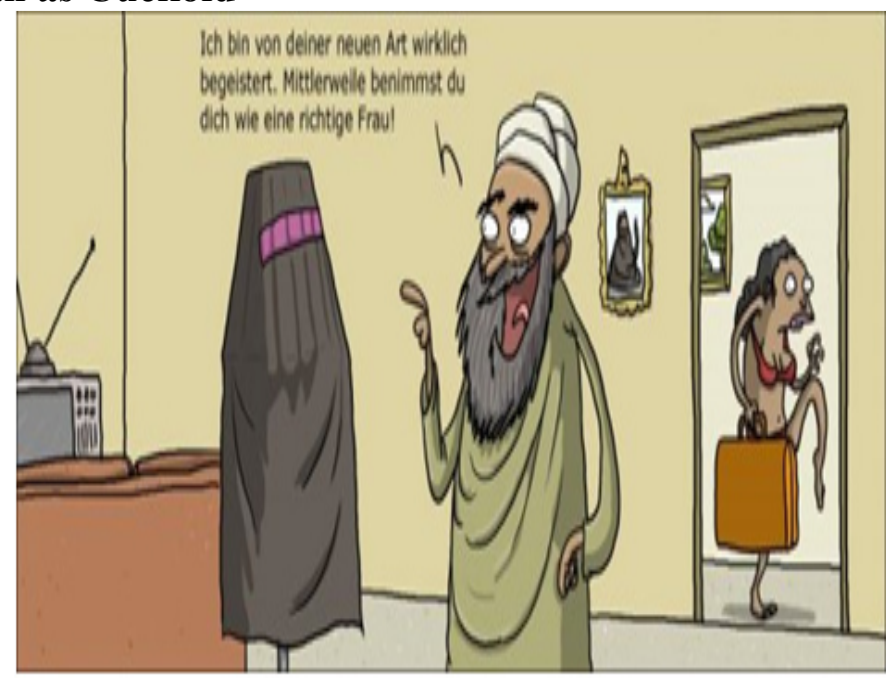

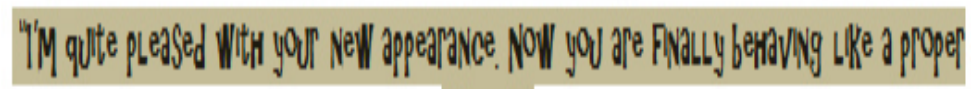

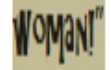

FIG 8

http://freethoughtblogs.com/taslima/2012/06/03/we-have-enough-muhammadcartoons-why-not-some-burqa-cartoons/

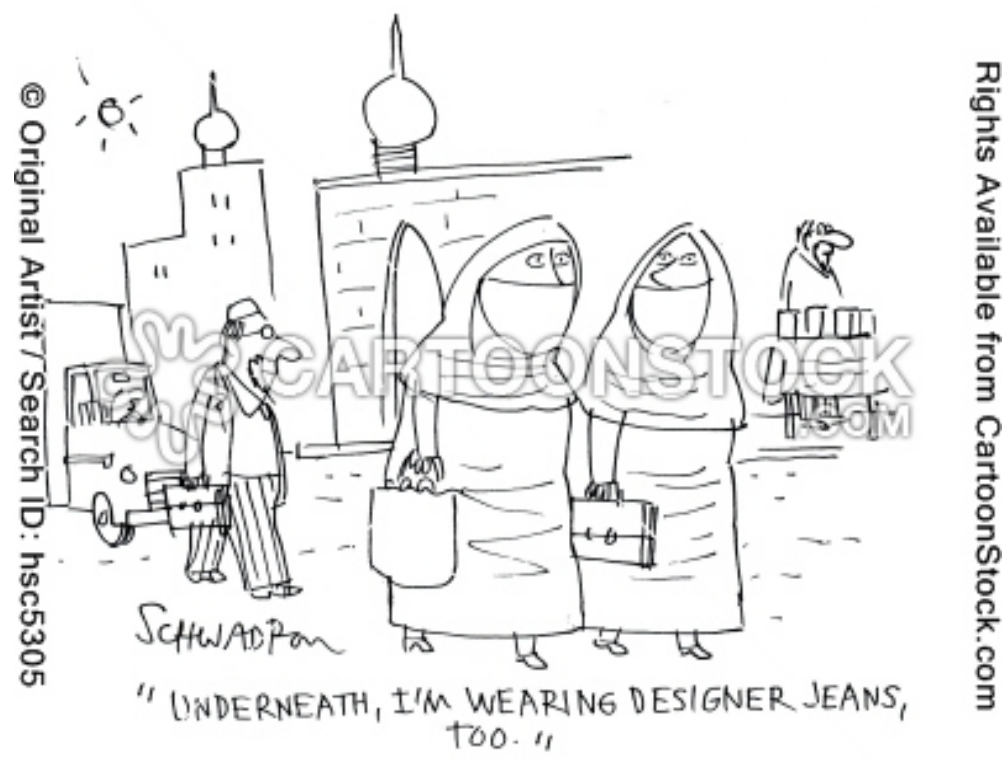

FIG 9

http://www.cartoonstock.com/d2irectory/i/islamic_beliefs.asp 


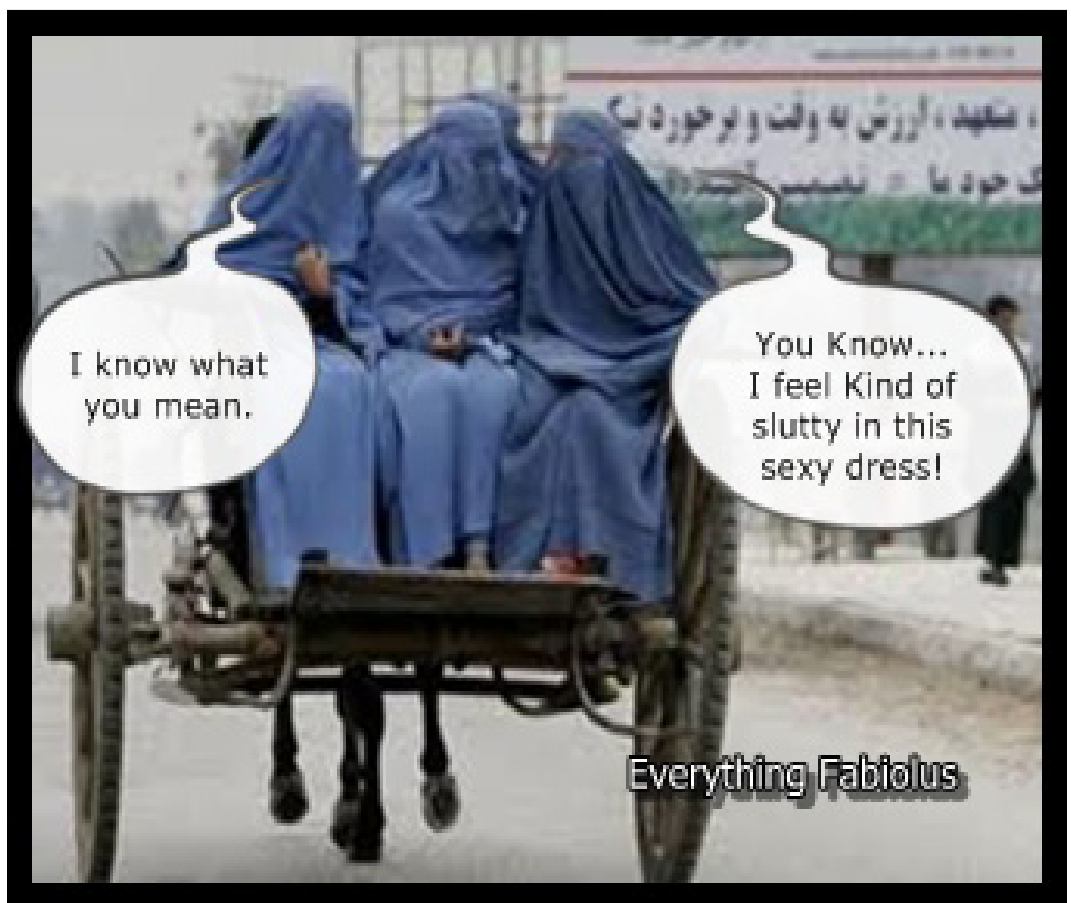

FIG 10

http://dr1.com/forums/clown-bin/133560-car-muslim-women.html

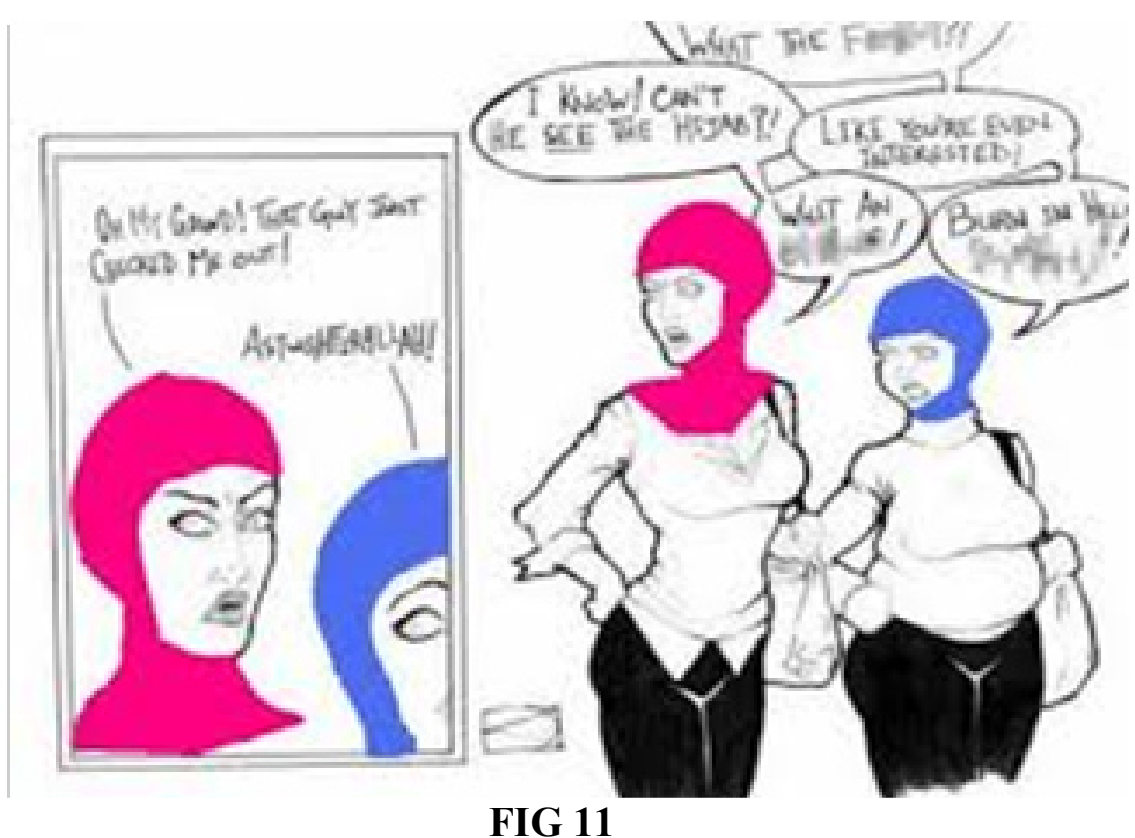

http://funnymuslimcomedy.blogspot.com/2012 


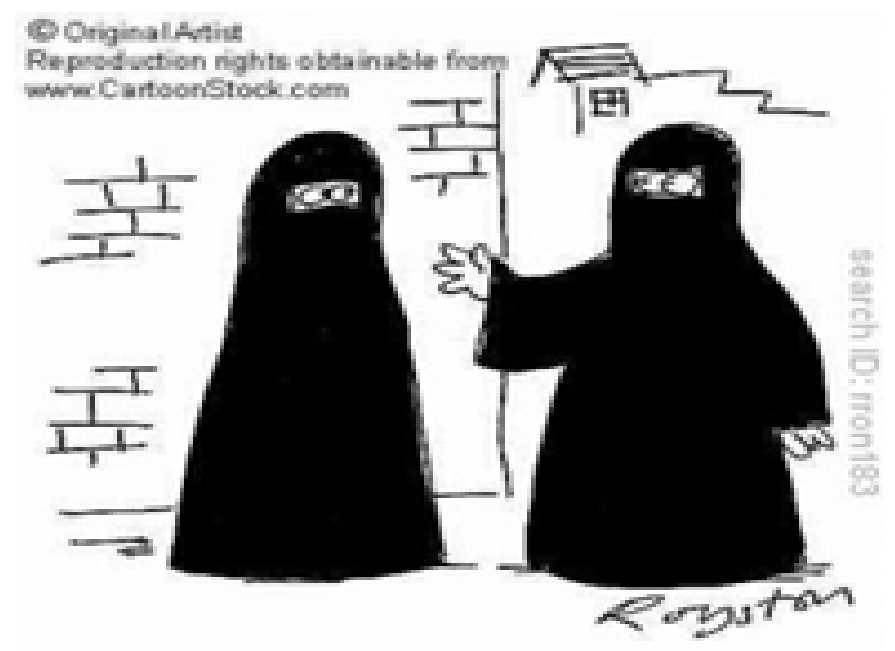

"Does my bum look big in this?"

FIG 12

http://freethoughtblogs.com/taslima/2012/06/03/we-have-enough-muhammadcartoons-why-not-some-burqa-scartoons/

\section{Muslim Woman's Social Role}

2.1 Muslim Women as Oppressed and Ignorant

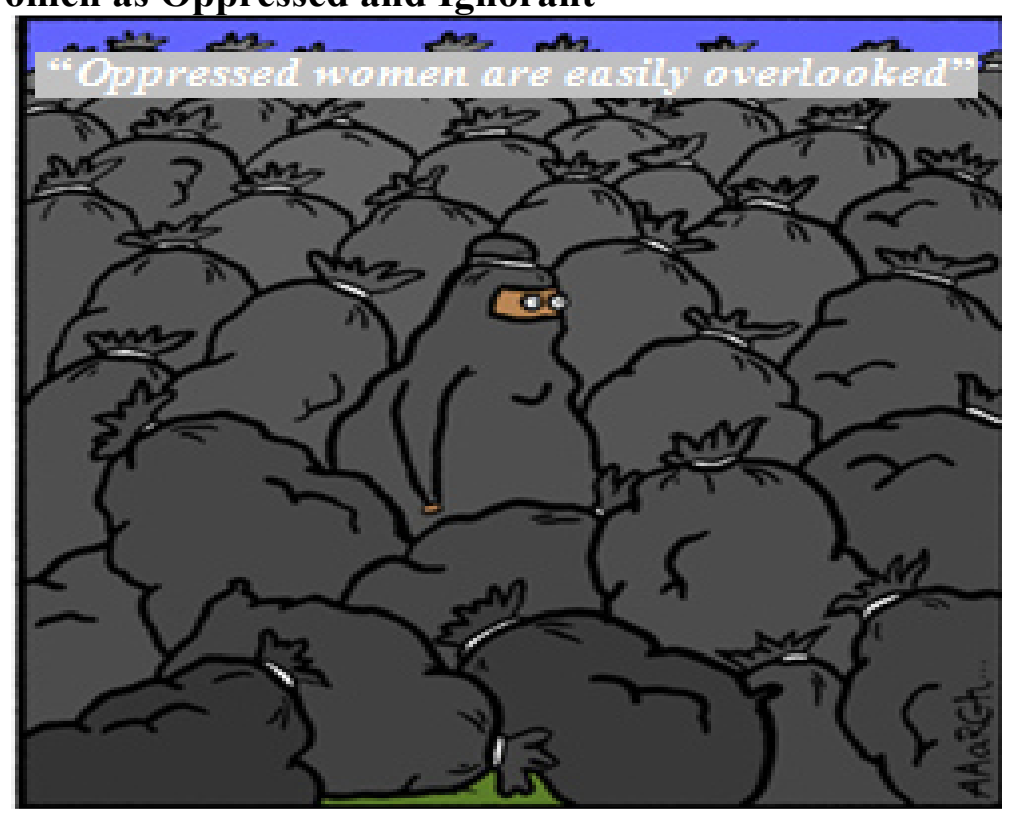

FIG 13

http://freethoughtblogs.com/taslima/2012/06/03/we-have-enough-muhammadcartoons-why-not-some-burqa-cartoons/ 


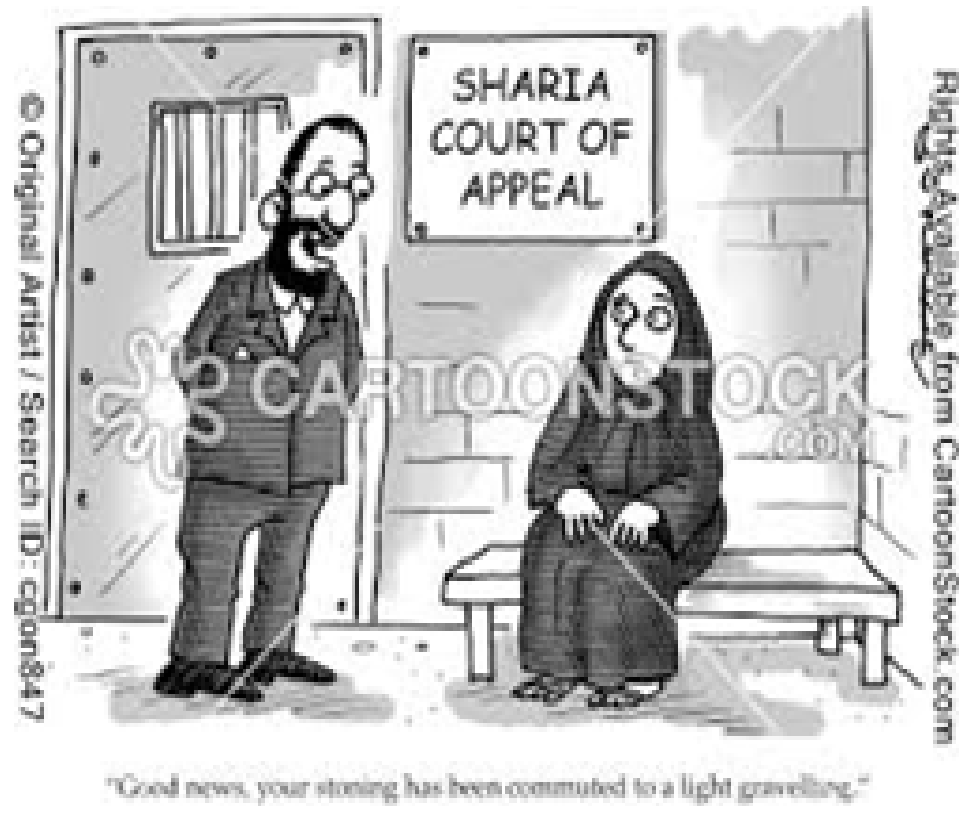

FIG 14

http://www.cartoonstock.com/directory/i/islamic.asp

Islamic Cartoons and Comics

Islamic cartoon 1 of 20

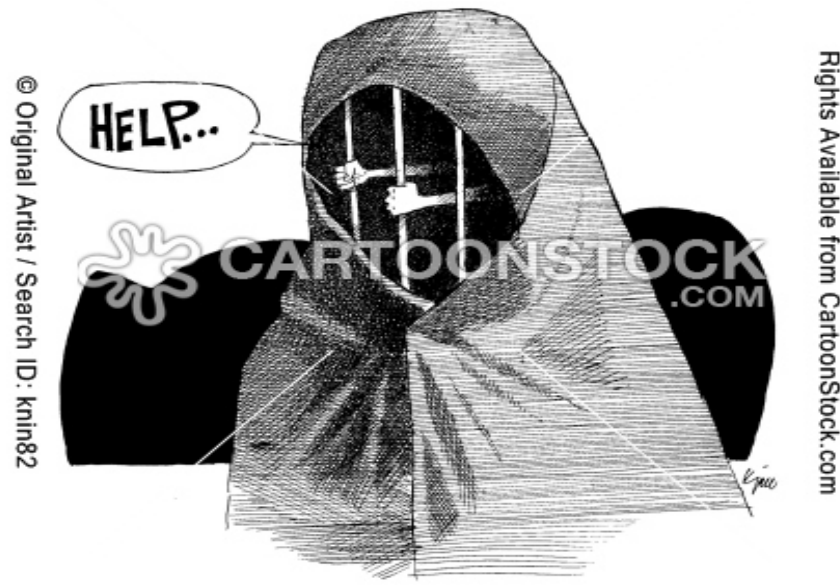

Women in Islam.

FIG 15

http://www.funny-joke-pictures.com/2013/09/funny-muslim-adam-even-gardeneden.htmls 


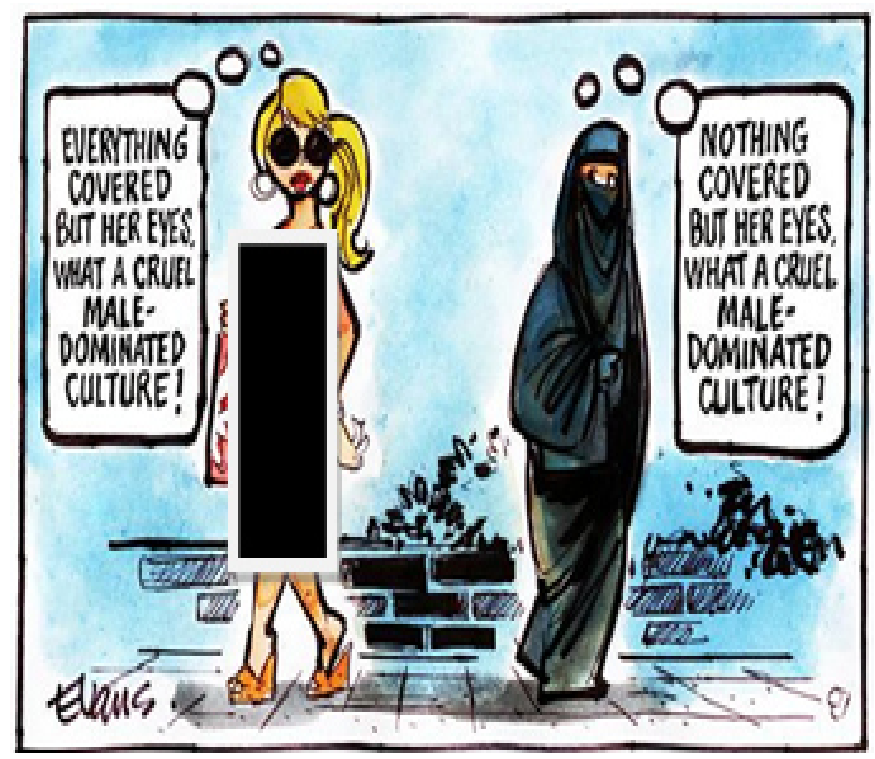

FIG 16

Republished in 2012http://www.patheos.com/blogs/mmw/2012/01/how-are-muslimwomen-doing-in-political-

$\underline{\mathrm{http}}$ //irishislamicstudiesstudentblog.wordpress.com/2013/06/13/symbolism-of-theveil-in-islam/http://thesocietypages.org/socimages/2012/02/22/questioning-definitionsof-freedom/

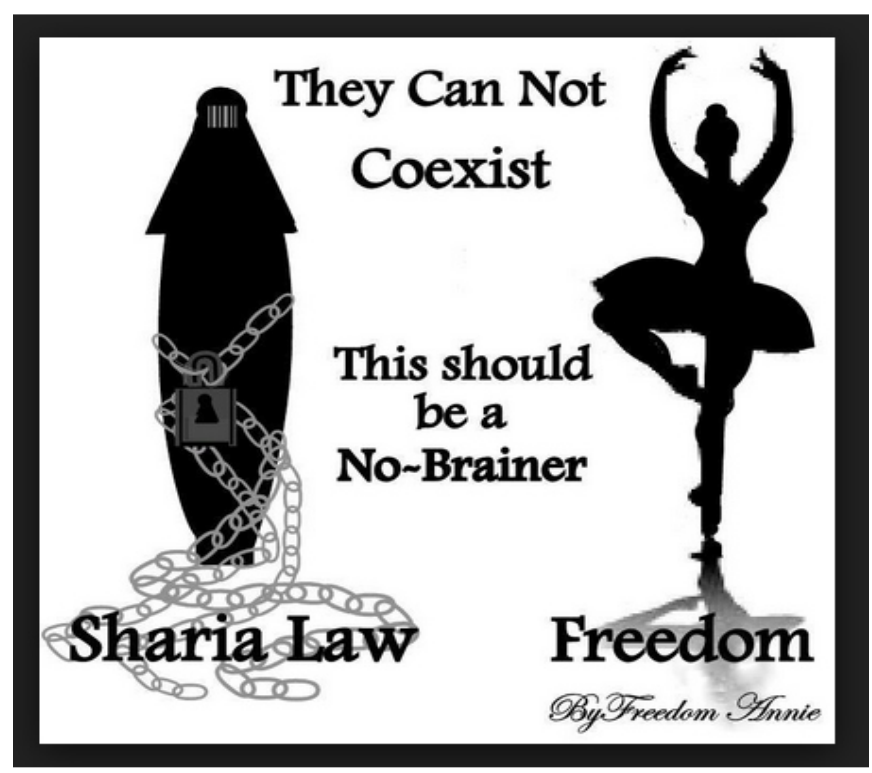

FIG 17

http://www.funny-joke-pictures.com/2013/09/funny-muslim-adam-even-gardeneden.html 


\subsection{Muslim Woman as a Social Recluse}

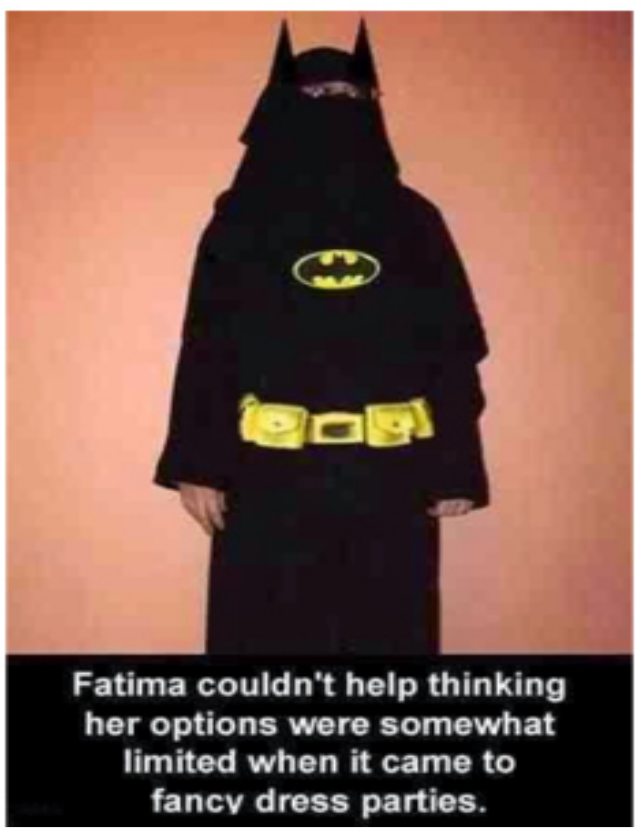

FIG 18

http://www.funny-joke-pictures.com/2013/09/funny-muslim-adam-even-gardeneden.html

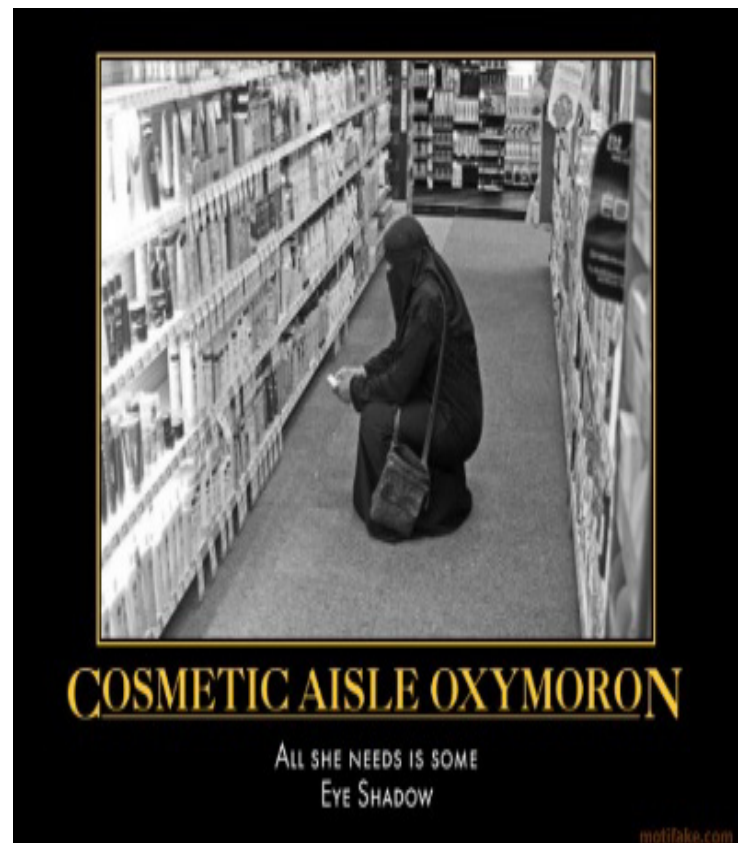

FIG 19

http://dr1.com/forums/clown-bin/133560-car-muslim-women.html 


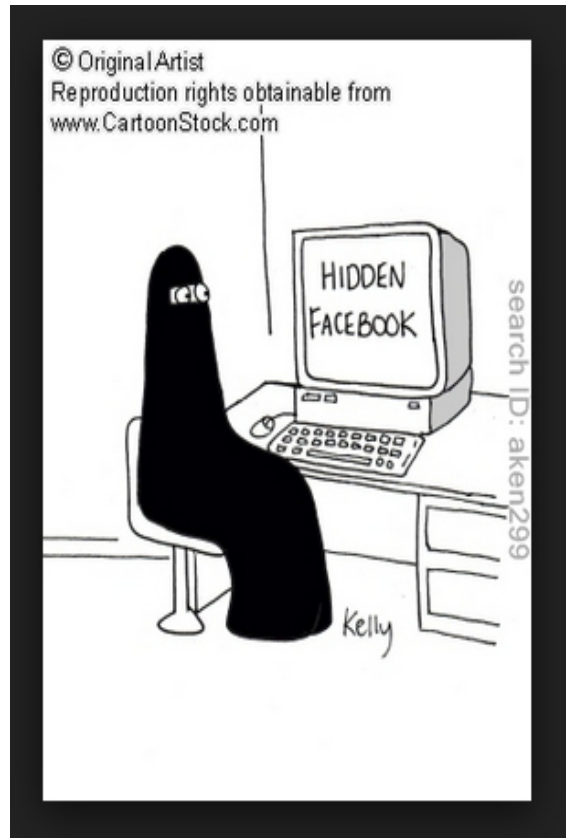

FIG 20

http://freethoughtblogs.com/taslima/2012/06/03/we-have-enough-muhammadcartoons-why-not-ssome-burqa-cartoons/

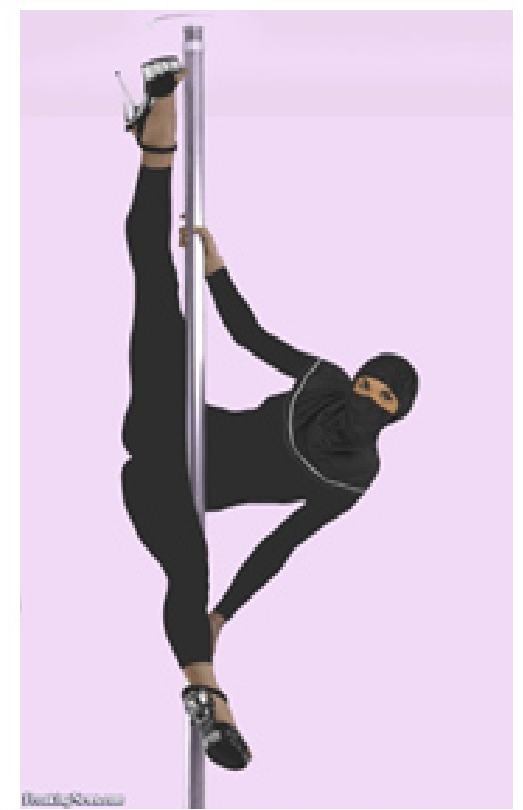

MUSUM POLE DanCER

FIG 21

http://www.freakingnews.com/Muslim-Pole-Dancer-Pictures-55701.asp 


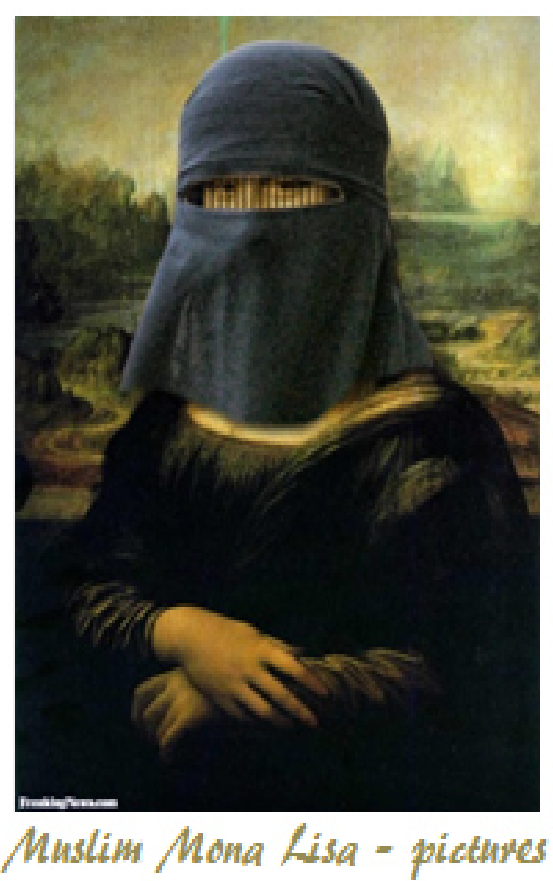

FIG 22

http://www.freakingnews.com/Muslim-Mona-Lisa-Pictures-87329.asp

Azka Khan is Lecturer in the Department of English, Fatima Jinnah Women University, Rawalpindi.

Dr. Sarwet Rasul is Chairperson and Associate Professor in the Department of English, Fatima Jinnah Women University, Rawalpindi. 